\title{
HASIL BELAJAR MUATAN BAHASA INDONESIA TEMA PEDULI TERHADAP MAKHLUK HIDUP MENGGUNAKAN REWARD PADA KELAS IV SDN 023 SAMARINDA UTARA
}

\author{
Hani Subakti \\ Universitas Widya Gama Mahakam Samarinda \\ Pos-el: hanisubakti@uwgm.ac.id
}

\begin{abstract}
ABSTRAK
Classroom action research (CAR) ini memiliki tujuan mengetahui hasil belajar muatan bahasa Indonesia siswa kelas IV SDN 023 Samarinda Utara. Dalam penelitian ini telah terjadi peningkatan yang signifikan pada hasil belajar muatan bahasa Indonesia tema peduli makhluk hidup dengan menggunakan reward pada kelas IV SDN 023 Samarinda Utara. Penelitian ini telah dilaksanakan sebanyak dua siklus. Tahap pelaksanaan setiap siklus terdiri dari perencanaan, pelaksanaan, pengamatan, dan refleksi. Teknik pengumpulan data menggunakan observasi, tes, wawancara, dan dokumentasi. Hasil akhir penelitian menunjukan bahwa pada siklus I hasil belajar siswa dengan nilai tes rata-rata 69,5 dengan presentase ketuntasan $60 \%$ dan presentase tidak tuntas yaitu $40 \%$. Sedangkan pada siklus II hasil belajar siswa dengan nilai tes rata-rata 81,3 meningkat dengan presentase ketuntasan $86,7 \%$ dan presentase tidak tuntas hanya $13,3 \%$. Berdasarkan hasil penelitian tersebut, maka dapat disimpulkan bahwa strategi reward dapat meningkatkan hasil belajar muatan bahasa Indonesia tema peduli makhluk hidup pada siswa kelas IV SDN 023 Samarinda Utara.
\end{abstract}

Kata Kunci: Hasil Belajar, Muatan Bahasa Indonesia, Tematik, Reward.

\begin{abstract}
This classroom action research (CAR) has the aim of learning the results of Indonesian language learning outcomes for grade IV SDN 023 North Samarinda. In this study, there has been a significant increase in research on Indonesian language learning themes in accordance with grade IV SDN 023 North Samarinda. This research has been carried out in two cycles. The implementation phase of each cycle consists of planning, acting, observing, and reflecting. Data collection techniques using observation, tests, interviews, and documentation. The final results of the study showed that in the first cycle students' learning outcomes with an average test score of 69.5 with a percentage of completeness $60 \%$ and an incomplete percentage of $40 \%$. While in cycle II student learning outcomes with an average test score of 81.3 increased with a percentage of completeness of $86.7 \%$ and the percentage of incomplete was only $13.3 \%$. Based on the results of the study, it can be concluded that the prize strategy can improve Indonesian learning outcomes Theme of caring about life in grade IV students of SDN 023 Samarinda Utara
\end{abstract}

Keywords: Learning Outcomes, Indonesian Content, Thematic, Reward.

\section{PENDAHULUAN}

Pendidikan merupakan salah satu pembinaan mutakhir bagi peradaban manusia untuk menjadi warga negara yang baik, sesuai dengan perkembangan akal pikiran manusia yang senantiasa mengalami, pertumbuhan, perkembangan, dan perubahan, Anwar (2017). Definisi tersebut dapat ditarik kesimpulan bahwa pendidikan 
merupakan proses pengembangan individu dan pengembangan karakter seseorang yang menjadikan warga negara menjadi baik dengan menjunjung tinggi keluhuran. Di sisi lain dapat menanamkan kaidah-kaidah atau nilainilai sebagai kesempurnaan kehidupan seseorang dengan kepribadian yang mantap dan mandiri serta rasa tanggung jawab bermasyarakat dan bangsa.

Tujuan pendidikan dan pembelajaran itu sendiri dapat tercapai bila kualitas guru dapat mendukung dalam proses pendidikan dan pembelajaran di sekolah. Karena apabila hal ini tidak menjadi faktor dominan dan utama, maka semua kegiatan yang dilakukan tidak akan dapat mencapai hasil yang diharapkan sesuai dengan rencana yang telah disusun. Seorang guru atau pendidik dituntut dapat membuat pembelajaran yang menarik, efektif, dan efisien. Akan tetapi banyak faktor yang menjadi penghambat di antaranya letak lingkungan sekolah yang berdekatan dengan rumah penduduk, situasi lingkungan sekitar sekolah yang tidak kondusif, serta adanya anak-anak di luar lingkungan sekolah yang bermain di dalam lingkungan sekolah. Hal ini disinyalisasi menganggu konsentrasi belajar siswa menyebabkan siswa kurang bersemangat dan berminat dalam belajar sehingga tidak mencapai kriteria ketuntasan minimal (KKM) yang diharapakan.

Ini terlihat dari hasil observasi awal penelitian yang telah dilakukan sebelumnya. Data yang diperoleh menunjukan rata-rata presentase hasil evaluasi harian siswa di SDN 023 Samarinda Utara berada di bawah standar kriteria ketuntasan minimal (KKM) dengan nilai 60-70\%. Nilai tersebut masih di bawah kriteria ketuntasan minimal (KKM) yang menjadi standar acuan nilai dengan di atas $70 \%$ sebagai batas nilai yang mencukupi standar kriteria ketuntasan minimal (KKM) di SDN 023 Samarinda
Utara. Atas dasar itu peneliti mencoba menggunakan reward sebagai motivasi dan minat belajar anak.

Reward adalah media atau alat penilaian yang bersifat positif terhadap hasil belajar siswa. Peranan reward dalam proses belajar mengajar ataupun pengajaran cukup penting terutama sebagai faktor eksternal memengaruhi dan mengarahkan perilaku siswa itu sendiri. Ini berdasarkan pertimbangan logis untuk menimbulkan motivasi belajar serta memengaruhi perilaku positif dalam kehidupan siswa. Dari permasalahan tersebut penulis merasa tertarik untuk melaksanakan penelitian yang berjudul "hasil belajar muatan bahasa Indonesia tema peduli terhadap makhluk hidup dengan mengggunakan reward pada siswa kelas IV SDN 023 Samarinda Utara

\section{METODE PENELITIAN}

Penelitian ini menggunakan metode penelitian deskriptif kualitatif. Penggunan metode ini bertujuan untuk meneliti suatu objek secara alamiah yang dideskripsikan secara akurat dan sistematis. Desain classrom action reasearch (CAR) atau dalam bahasa Indonesia penelitian tindakan kelas (PTK) memiliki tujuan memperbaiki dan meningkatkan kualitas pembelajaran serta dapat membantu memberdayakan guru dalam memecahkan masalah pembelajaran yang ada di sekolah. Tujuan penelitian ini adalah berupaya untuk memperbaiki praktik pembelajaran yang selama ini dirasa kurang baik agar menjadi lebih efektif dan efisien. Untuk mencapai itu semua pembelajaran di dalam kelas harus memiliki suasana belajar yang nyaman bagi guru dan bagi peserta didik.

Arikunto, Suhardjono, \& Supardi (2016) mendefinisikan model penelitian tindakan kelas (PTK) merupakan penelitian eksperimen yang berulang atau eksperimen berkelanjutan, meskipun tidak selalu demikian adanya. 
Apabila guru atau pendidik tidak puas dengan hasil pembelajarannya dan berkeinginan mengubah pembelajaran itu dengan model yang sifatnya baru dipersilakan mencobanya tidak hanya satu kali saja tapi berulang-ulang sehingga penelitian itu sering disebut penelitian tindakan.

Kunandar (2013) menyatakan pelaksanaan tindakan kelas (PTK) meliputi beberapa aspek di antaranya:

1) Perancanaan (planning):

a) Semua langkah tindakan secara rinci;

b) Segala keperluan pelaksanaan PTK

c) Pikiran kendala yang mungkin timbul pada pelaksanaan;

2) Pelaksanaan (acting) tindakan: realisasi dari teori dan teknik mengajar serta tindakan (treatment) yang sudah direncanakan sebelumnya;
a) Pengamatan tindakan (pengumpulan data dan informasi).

b) Penggunaan teknik pengumpulan data dalam penelitian tindakan kelas (PTK) ditentukan oleh sifat dasar data yang akan dikumpulkan. Aspek yang diamati adalah (1) proses tindakan; (2) pengaruh tindakan; (3) keadaan dan kendala; (4) bagaimana keadaan, kendala tersebut menghambat atau mempermudah tindakan yang telah direncanakan dan pengaruhnya; (5) persoalan yang lain yang timbul selama kegiatan penelitian tindakan kelas (PTK) data penelitian tindakan berfungsi sebagai landasan untuk melakukan refleksi.

Penelitian tindakan kelas (PTK) tidak bersifat instan, cepat jadi, ataupun langsung memberikan perubahan dalam waktu yang relatif singkat. Siklus sendiri berasal dari kata siklus yang berarti memiliki tahapan-tahapan yang merupakan proses dari sebuah perbaikan yang dilakukan. Sehingga dapat disimpulkan bahwa siklus bermakna berproses dan berulang artinya bahwa penelitian tindakan kelas (PTK) tidak dapat dilakukan hanya dalam satu kali tindakan akan tetapi merupakan tindakan yang berkelanjutan sehingga memberikan perubahan dalam tiap proses dan hasil pembelajaran di kelas.

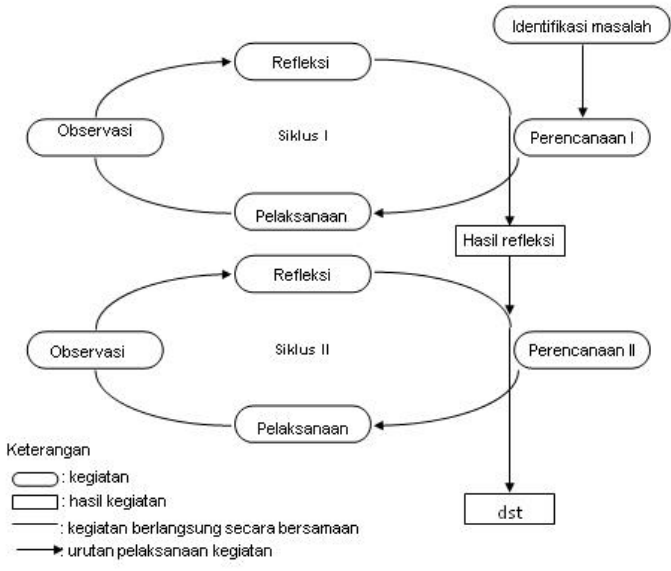

Penelitian dilaksanakan pada semester ganjil di kelas IV SDN 023 Samarinda Utara yang beralamat di Jalan Solong Durian, Kelurahan Sempaja Utara, Kecamatan Samarinda Utara, Kota Samarinda.

Subjek dalam penelitian tindakan kelas (PTK) ini yaitu seluruh siswa kelas IV SDN 023 Samarinda. Penelitian tindakan kelas (PTK) ini dilakukan melalui empat tahap yaitu perencanaan, pelaksanaan, pengamatan, dan refleksi. Penelitian yang dilakukan terdiri dari 2 siklus, di mana setiap siklus terdiri dari 3 kali pertemuan. Pertemuan pertama dan kedua untuk menyampaikan materi, sedangkan pertemuan ketiga dilaksanakan untuk pemberian tes pada siswa.

Pelaksanaan penelitian tindakan kelas (PTK) dimulai dengan siklus I yang terdiri dari empat bagian. Apabila sudah diketahui letak keberhasilan dan hambatan dari tindakan yang dilaksanakan pada siklus pertama tersebut, peneliti menentukan rencana 
untuk siklus kedua, kegiatan pada siklus II hampir sama dengan kegiatan sebelumnya yang ditujukan untuk menyakinkan/menguatkan hasil. Tetapi umumnya kegiatan yang dilakukan pada siklus II mempunyai berbagai tambahan perbaikan dari tindakan terdahulu yang tentu saja ditujukan untuk memperbaiki berbagai hambatan dan kesulitan yang ditentukan dalam siklus I.

Observasi atau pengamatan merupakan cara yang digunakan untuk mengumpulkan data, di sini peneliti menggunakan observasi partisipatif. Di mana peneliti melakukan pengamatan dan ikut berpartisipasi dalam kegiatan dengan sumber data yaitu peserta didik. Observasi merupakan pengamatan langsung menggunakan alat indera atau instrumen sebagai alat bantu penginderaan suatu subjek atau objek. Dalam teknik pengumpulan data ini peneliti menggunakan tes di mana peneliti melakukan pengukuran secara keseluruhan. Mencangkup sikap, persepsi, pendapat, dan pengalaman siswa.

Tes sebagai instrumen yang baik digunakan dalam penelitian tindakan kelas (PTK). Hal ini disebabkan dalam PTK salah satu yang diukur adalah aspek psikologis itu dapat berupa prestasi atau hasil belajar, minat bakat, sikap kecerdasan, reaksi motorik, dan berbagai aspek kepribadian lainnya. Tes yang diberikan adalah tes tertulis dengan bentuk soal essay dengan jumlah 10 soal dengan keseluruhan soal merupakan uraian yang sudah disiapkan oleh peneliti dalam melakukan kegiatan tes tersebut.

Wawancara merupakan bentuk komunikasi verbal semacam percakapan yang bertujuan mendapatkan informasi eksklusif. Mengumpulkan data dengan melakukan tanya jawab yang dilakukan berlandaskan pada tujuan penelitian yang dilakukan kepada siswa yang hadir secara fisik dalam tanya jawab. Wawancara ini dilakukan pada peserta didik sesudah mengikuti pembelajaran, untuk itu peneliti menyiapkan sebuah pertanyaan yang sudah dipersiapkan dan catatan dengan menggunakan notebook serta kamera handphone untuk memotret pada saat peneliti melakukan pembicaraan dengan sumber data.

Dokumentasi adalah salah satu cara mencari data dengan melihat bendabenda tertulis, berupa catatan harian/lapangan, dokumen-dokumen, notulen, nilai siswa dan sebagainya. Dokumen ini sebagai bahan pendukung untuk memperkuat hasil penelitian.

Data yang diperoleh dari observasi dan evaluasi langsung dianalisis sesuai dengan indikator untuk mengetahui permasalahan dalam penelitian yang dilakukan pada dua siklus dengan perhitungan nilai menggunakan rumus sebagai berikut:

Perhitungan Rata-Rata Nilai Siswa

$\mathbf{X} \frac{\sum \mathbf{x}}{\sum \mathbf{N}}$

Keterangan:

$\mathrm{X}=$ nilai rata-rata

$\sum \mathbf{x}=$ jumlah nilai siswa

$\sum \mathbf{N}=$ jumlah siswa yang mengikuti tes

(Sudjana, 2016).

Kriteria Keberhasilan Proses

Pembelajaran Siswa dalam Presentase

\begin{tabular}{|l|l|l|l|}
\hline $\begin{array}{l}\text { Nilai } \\
\text { Siswa }\end{array}$ & $\begin{array}{l}\text { Nilai } \\
\text { Huruf }\end{array}$ & $\begin{array}{l}\text { Fruekuensi } \\
\text { (Jumlah siswa) }\end{array}$ & Kriteria \\
\hline $80-100$ & A & 1 & Baik Sekali \\
\hline $66-79$ & B & 18 & Baik \\
\hline $56-65$ & C & 6 & Cukup \\
\hline $40-55$ & D & 4 & Kurang \\
\hline $30-39$ & E & 1 & Kurang Sekali \\
\hline
\end{tabular}

(Sudjana, 2016)

Perhitungan Ketuntasan Belajar

Dalam penelitian ini terdapat dua kategori ketuntasan belajar yaitu secara individu dan klasikal. Ketuntasan belajar secara individual didapat dari KKM untuk pembelajaran ditetapkan sekolah yaitu siswa dinyatakan tuntas jika telah mendapatkan nilai sekurang-kurangnya 70 dan jika di bawah 70 dinyatakan 
belum tuntas. Sedangkan ketuntasan belajar secara klasikal yaitu mengukur tingkat keberhasilan ketuntasan belajar siswa menyeluruh. Untuk menghitung persentase ketuntasan belajar klasikal digunakan rumus:

$\mathrm{P}=\frac{\sum \text { jumlah siswa yang mendapat nilai }}{\sum \text { jumlah siswa mengikuti tes }} \times 100 \%$

Keterangan: $\mathrm{P}=$ presentase ketuntasan

(Sudjana, 2016)

Indikator keberhasilan dalam penelitian ini dapat diukur dari meningkatnya hasil belajar yaitu $80 \%$ siswa dari jumlah keseluruhan siswa di dalam kelas dengan kriteria sesuai KKM yang sudah ditentukan oleh peneliti.

\section{HASIL DAN PEMBAHASAN Hasil Penelitian}

Penelitian dilaksanakan di SDN 023 Samarinda Utara yang beralamat di Jalan Solong Durian Kelurahan Semapaja Utara, Kecamatan Samarinda Utara, Kota Samarinda. Subjek penelitian siswa kelas IV dengan jumlah siswa 30 orang siswa terdiri dari 16 siswa laki-laki dan 14 siswa perempuan, dilaksanakan pada semester 1 Tahun pembelajaran 2019/2020.

\section{Siklus I}

Siklus I terdiri dari 3 kali pertemuan di kelas. Waktu pembelajaran yang digunakan disetiap pertemuan adalah 70 menit, dengan keseluruhan waktu pembelajaran yang digunakan pada siklus I adalah 210 menit. Dalam penelitian ini, siklus I dilaksanakan dengan empat tahapan yaitu:

\section{1) Perencanaan}

Berdasarkan hasil nilai yang dilaksanakan sebelumnya, nilai siswa kelas IV dari 30 siswa, yang mencapai kriteria ketuntasan minimal (KKM) yaitu 10 orang siswa $(14.2 \%)$ sedangkan 20 orang $(85.8 \%)$ belum mencapai kriteria ketuntasan minimal (KKM). Oleh karena itu dilakukan penelitian menggunakan reward untuk meningkatkan hasil belajar muatan bahasa Indonesia pada kelas IV dengan menyusun langkah-langkah perencanaan pembelajaran sebagai berikut:

a. Menyiapkan rencana
pelaksanaan (RPP)

b. Menyiapkan lembar kerja siswa (LKS)

c. Menyiapkan soal evaluasi untuk melihat tingkat hasil belajar pada siklus I

d. Menyiapkan lembar wawancara

e. Menyiapkan lembar observasi

f. Menyiapkan reward

2) Pelaksanaan

Pada tahap pelaksanaan ini dilakukan 3 kali pertemuan di mana pertemuan satu dan dua menyampaikan materi sedangkan pertemuan ketiga melakukan tes hasil belajar siswa. Tindakan siklus I dilaksanakan tiga kali pertemuan, dua kali pertemuan untuk mengajarkan materi dan pertemuan ketiga tes. Selama pembelajaran ada beberapa masalah yang dihadapi pada siklus I siswa masih banyak bercerita di dalam kelas tidak memperhatikan penjelasan peneliti dan berjalan-jalan ke bangku temannya dan izin berkali-kali ke toilet. Pada saat peneliti menjelaskan kontrak reward dan poin-poin pembelajaran di kelas menjadi ribut sehingga situasi kelas menjadi sangat ramai dan waktu yang digunakan menjadi sangat lama ada sekitar 4 orang siswa yang berteriak di dalam kelas. 7 orang siswa lainnya sibuk bercerita dengan temannya dan tidak memperhatikan penjelasan. Terdapat beberapa siswa yang masih kebingungan dalam pembelajaran dengan menggunakan reward sehingga membutuhkan waktu yang cukup lama dalam menjelaskan kontrak reward yang disampaikan.

Sedangkan pertemuan kedua siklus satu, guru menggunakan reward untuk menarik minat belajar dan 
motivasi belajar siswa dalam mengikuti pembelajaran dengan membagi 6 kelompok dengan setiap kelompok beranggotakan 5 orang siswa yang ditentukan oleh guru untuk melakukan kegiatan pembelajaran dengan gim. Namun hal yang ditemui masih sama pada pertemuan pertama, siswa pada pertemuan kedua masih ribut, tidak mau mendengar penjelasan peneliti di depan kelas dan sibuk mengobrol dengan temannya serta mengganggu temannya, hanya ada beberapa siswa yang bersemangat dan termotivasi dengan menggunakan reward sebagai motivasi dan menarik minat belajar. Pertemuan ketiga siklus satu, guru mengulang kembali materi yang disampaikan pada pertemuan satu dan dua sebelum melakukan tes.

Hasil belajar siswa pada siklus I sudah tergolong cukup dengan nilai ratarata 69,5. Adapun peningkatan hasil belajar dari kondisi awal ke siklus I sebesar $30,5 \%$ analisis hasil siswa dapat dilihat pada tabel bawah ini.

Analisis Kriteria Hasil Belajar Siswa pada Siklus I

\begin{tabular}{|c|c|c|c|}
\hline $\begin{array}{c}\text { Nilai } \\
\text { Siswa }\end{array}$ & $\begin{array}{c}\text { Nilai } \\
\text { Huruf }\end{array}$ & $\begin{array}{c}\text { Fruekuensi } \\
\text { (Jumlah } \\
\text { siswa) }\end{array}$ & Kriteria \\
\hline $80-100$ & A & 8 & Baik Sekali \\
\hline $66-79$ & B & 11 & Baik \\
\hline $56-65$ & C & 7 & Cukup \\
\hline $40-55$ & D & 4 & Kurang \\
\hline $30-39$ & E & - & Kurang Sekali \\
\hline
\end{tabular}

Hasil Belajar Siswa pada Siklus I

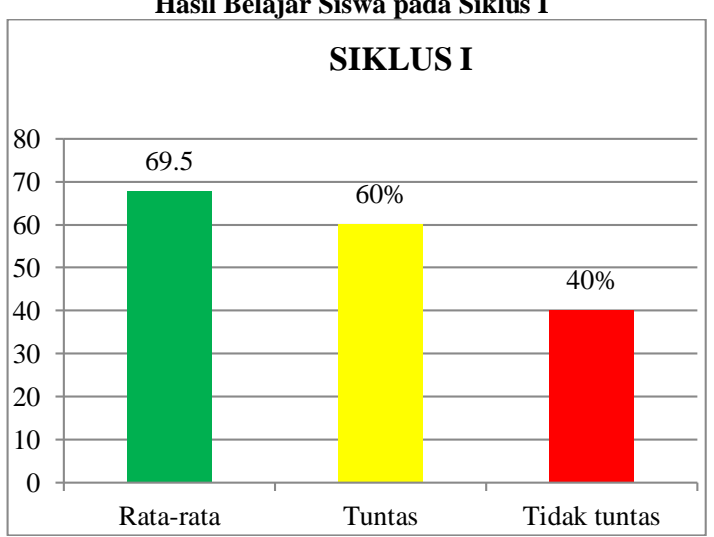

Dari hasil wawancara yang dilakukan oleh peneliti, selama belajar mengajar di kelas belum pernah sama sekali menggunakan reward dalam kegiatan pembelajaran sehingga siswa merasa bosan, tidak berminat, dan tidak termotivasi dalam kegiatan pembelajaran tersebut.

Hasil dari observasi pada siklus I pertemuan pertama, pertemuan kedua, dan pertemuan ketiga. Dengan alokasi waktu 6 x 35 menit (3 kali pertemuan). Selama tiga kali pertemuan banyak masalah yang muncul. Banyak siswa yang tidak mau bergabung dengan kelompok siswa lainnya dan banyak siswa yang ribut, sehingga menciptakan suasana kelas yang kurang kondusif. Akibatnya siswa tidak dapat berkonsentrasi dengan baik.

Setelah melaksanakan kegiatan pembelajaran pada siklus I, kemudian peneliti melakukan refleksi terhadap proses kegiatan pembelajaran. Refleksi digunakan sebagai bahan pertimbangan untuk melanjutkan kegiatan pembelajaran pada siklus II. Berdasarkan data-data yang diperoleh peneliti dapat menyimpulkan bahwa dari hasil tes evaluasi diakhir siklus menunjukan bahwa hasil belajar pada siklus I yaitu dengan rata-rata 69,5. Dari hasil tersebut menunjukan belum mencapai KKM yaitu $\geq 70$ dari keseluruhan yang belum mencapai $\mathrm{KKM} \geq 80 \%$ maka dari itu dilanjutkan pada siklus II.

\section{Siklus II}

Siklus II terdiri dari 3 kali pertemuan. Waktu pembelajaran yang digunakan disetiap pertemuan adalah 70 menit. Dengan keseluruhan waktu pembelajaran yang digunakan pada siklus II adalah 210 menit. Dalam penelitian ini, siklus II dilaksanakan dengan empat tahapan yaitu:

1) Perencanaan

Berdasarkan hasil refleksi pelaksanaan pada siklus I telah diketahui bahwa belum adanya peningkatan hasil belajar muatan bahasa Indonesia yang signifikan pada siswa dengan menggunakan reward. Oleh, karena itu perlu dilakukan perencanaan yang 
matang pada siklus II. Peneliti memberikan arahan kembali pada siswa, memperbaiki pengolahan kelas. Peneliti menyusun langkah-langkah perencanaan pembelajaran sebagai berikut:

1. Menyiapkan rencana pelaksanaan pembelajaran (RPP)

2. Menyiapkan lembar kerja siswa (LKS)

3. Menyiapkan soal evaluasi untuk melihat tingkat hasil belajar pada siklus II

4. Menyiapkan lembar wawancara

5. Menyiapkan lembar observasi

6. Menyiapkan reward

2) Pelaksanaan

Pada tahap pelaksanaan ini dilakukan 3 kali pertemuan di mana pertemuan satu dan dua menyampaikan materi sedangkan pada pertemuan ketiga melakukan tes hasil belajar siswa. Pada siklus II dilaksanakan tiga kali pertemuan, dua kali pertemuan untuk mengajarkan materi dan pertemuan ketiga tes. Selama pelaksanaan pembelajaran ada beberapa masalah yang dihadapi oleh peneliti yaitu masih ada beberapa siswa yang sibuk berbicara dengan temannya pada saat peneliti menjelaskan. Akan tetapi pada siklus ini siswa terlihat lebih aktif dan siap mengikuti pembelajaran dari siklus I.

Pada saat peneliti meminta untuk menyiapkan ruang kelas untuk memulai kegiatan pembelajaran masih ada beberapa siswa yang masih sibuk berbicara pad. Akan tetapi pada saat pembelajaran dimulai terlihat siswa sangat berminat dan termotivasi mengikuti kegiatan pembelajaran dan terlihat lebih siap mengikuti pembelajaran. Ini terlihat siswa lebih aktif dan siap dalam belajar.

Pada pertemuan kedua ini guru melanjutkan materi dari pertemuan pertama dengan menggunakan reward, siswa terlihat antusias dan bersemangat dalam belajar dan siswa terlihat lebih siap mengikuti pembelajaran serta siswa tidak mengalami kesulitan mengikuti gim dibandingkan dengan siklus satu siswa mengalami kesulitan dalam menyusun gim dan terjadi keributan antara kelompok satu dengan yang lainnya. Pertemuan ketiga ini guru mengulang kembali materi yang disampaikan pada pertemuan satu dan dua sebelum melakukan tes.

Hasil belajar siswa pada siklus II sudah tergolong baik dengan nilai ratarata 81,3. Adapun peningkatan hasil belajar siswa dari siklus I ke siklus II sebesar 18,7\%. Analisis hasil belajar siswa pada siklus II dapat dilihat pada tabel di bawah ini.

Analisis Kriteria Hasil Belajar Siswa pada Siklus II
\begin{tabular}{|c|c|c|c|}
\hline $\begin{array}{c}\text { Nilai } \\
\text { Siswa }\end{array}$ & $\begin{array}{c}\text { Nilai } \\
\text { Huruf }\end{array}$ & $\begin{array}{c}\text { Fruekuensi } \\
\text { (Jumlah } \\
\text { siswa) }\end{array}$ & Kriteria \\
\hline $80-100$ & A & 20 & Baik Sekali \\
\hline $66-79$ & B & 6 & Baik \\
\hline $56-65$ & C & 4 & Cukup \\
\hline $40-55$ & D & - & Kurang \\
\hline $30-39$ & E & - & Kurang Sekali \\
\hline
\end{tabular}

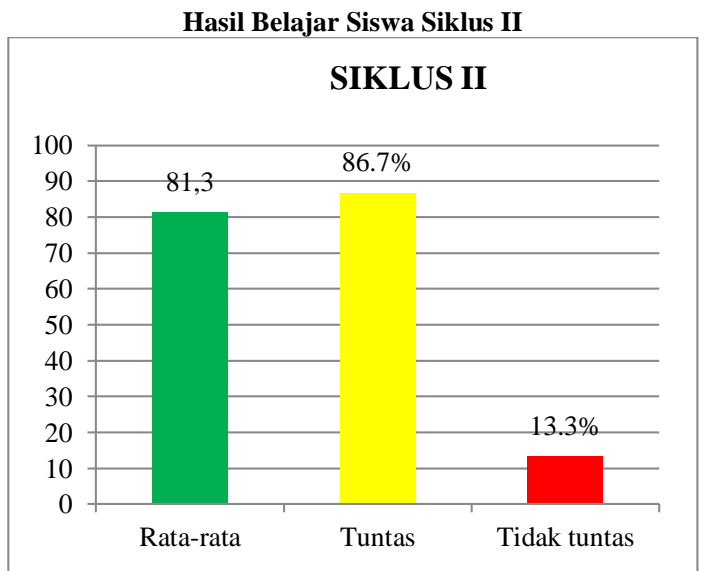

Dari hasil wawancara yang dilakukan oleh peneliti, selama belajar menggunakan reward kegiatan pembelajaran membuat siswa termotivasi dan aktif dalam kegiatan pembelajaran tersebut.

Hasil dari observasi pada siklus II pertemuan pertama, pertemuan kedua, dan pertemuan ketiga yang dilaksanakan dengan alokasi waktu 6 x 35 menit $(3 \times$ pertemuan). Selama pertemuan disiklus ini siswa terlihat lebih semangat dan siap dalam mengikuti kegiatan pembelajaran yang sedang berlangsung. Kemudian 
peneliti melanjutkan dengan menjelaskan materi dalam penerapan pembelajaran menggunakan reward dengan materi.

Setelah melaksanakan kegiatan pembelajaran pada siklus II, kemudian peneliti melakukan refleksi terhadap proses kegiatan pembelajaran. Refleksi ini digunakan sebagai bahan pertimbangan untuk melanjutkan kegiatan pembelajaran. Berdasarkan data-data yang diperoleh, peneliti dapat menyimpulkan bahwa dari hasil tes evaluasi diakhir siklus ini menunjukan bahwa hasil belajar pada siklus II mengalami peningkatan dan hasil ketuntasan belajar siswa kelas IV SDN 023 Samarinda Utara telah mencapai $81,33 \%$. Dari hasil tersebut peneliti dinyatakan berhasil dan penelitian pun dihentikan.

Keterbasan selama penelitian tindakan kelas (PTK) yang dialami oleh penliti selama pelaksanaan penelitian tindakan kelas (PTK) ini adalah masalah pertama sekolah yang berdekatan dengan rumah-rumah penduduk, masalah kedua penguasaan kelas, masalah ketiga ada beberapa siswa yang sulit diatur di dalam proses pembelajaran, masalah keempat pada saat pembagian kelompok ada siswa yang tidak mau berkelompok dengan teman kelompoknya.

\section{SIMPULAN}

Simpulan dalam ini ditemukan bahwa pembelajaran menggunakan reward pada muatan bahasa Indonesia dapat meningkatkan hasil belajar siswa kelas IV SDN 023 Samarinda Utara Tahun Pembelajaran 2019/2020. Hal ini dapat dilihat dari ketuntasan belajar pada siklus I dan siklus II. Ketuntasan belajar tersebut menunjukan peningkatan dari nilai prasiklus semester I yaitu $33.5 \%$ menjadi $40 \%$ di siklus I, kemudian sampai akhirnya meningkat menjadi $81,3 \%$ di siklus II. Diharapkan dapat menggunakan pembelajaran yang menarik, kreatif, dan aktif secara tepat dalam kegiatan belajar mengajar sehingga dapat menciptakan rasa senang kepada anak dalam pembelajaran sehingga membuat anak lebih semangat, aktif, dan hasil belajar dapat meningkat.

\section{DAFTAR PUSTAKA}

Anwar, M. (2015). Filsafat Pendidikan. Jakarta: Kencana.

Arikunto, S., Suhardjono, \& Supardi. (2016). Penelitian Tindakan Kelas (2nd Ed.). Jakarta: Bumi Aksara.

Ahmadi, R. (2014). Pengantar Pendidikan (Asas \& Filsafat Pendidikan). Yogyakarta: ArRuzz Media.

Kunandar. (2013). Langkah Mudah Penelitian Tindakan kelas Sebagai Pengembangan Profesi Guru (9th Ed.). Depok: Rajagrafindo Persada.

Kompri. (2015). Motivasi Pembelajaran Perspektif Guru Dan Siswa. Bandung: Remaja Rosdakarya.

Kurniawan, D. (2017). Pembelajaran Terpadu Tematik (Teori, Praktik, Dan Penilaian). Bandung: Alfbeta.

Paizaluddin dan Ermalinda. (2014). Penelitian Tindakan Kelas (Classroom Action Research). Bandung: Alfabeta.

Setiawan, R. (2017). Penelitian Tindakan Kelas (Action Research) (1st Ed.). Yogyakarta: Nuha Medika.

Sugiyono. (2015). Metode Penelitian Pendidikan. Bandung: Alfabeta.

Susanto, A. (2016). Teori Belajar Dan Pembelajaran Di Sekolah Dasar. Jakarta: Kencana.

Thobroni, M. (2015). Belajar \& Pembelajaran (Teori dan Praktik). Yogyakarta: Ar-Ruzz Media.

Widiasworo, E. (2017). MasalahMasalah Peserta Didik alam Kelas Dan Solusinya. Yogyakarta: Aksara. 
Yaumi, M. (2014). Pendidikan Karakter Landasan, Pilar \& Implementasi. Jakarta: Kencana. 